\title{
GIDANIN ÖZELLEŞTİRİLMESİ VE DETAYLANDIRILMASINDA ÜÇ BOYUTLU (3D) YAZICININ KULLANIMI
}

\author{
Hilal Meral*, Aslıhan Demirdöven \\ Tokat Gaziosmanpaşa Üniversitesi, Mühendislik ve Mimarlık Fakültesi Gıda Mühendisliği Bölümü, Tokat, \\ Türkiye
}

Geliş / Received: 04.08.2021; Kabul / Accepted: 27.01.2022; Online bask1 / Published online: 04.02.2022

Meral, H., Demirdöven, A. (2022). Gıdanın özelleştirilmesi ve detaylandırılmasında üç boyutlu (3D) yazıcının kullanımı. GIDA (2022) 47 (1) 91-106 doi: 10.15237/gida. GD21112.

Meral, H., Demirdöven, A. (2022). Three-dimensional (3D) printing technology in customizing and elaborating of food. GIDA (2022) 47 (1) 91-106 doi: 10.15237/gida. GD21112.

ÖZ

Üç boyutlu (3D) yazıcı teknolojisi, oldukça karmaşık geometrik yapılara sahip üç boyutlu nesnelerin üretiminde büyük esneklik sunarak, daha önce erişilemeyen özelliklere ve ilgi çekici işlevlere olanak tanımaktadır. Katmanlı üretim veya hızlı prototipleme olarak da ifade edilen üç boyutlu yazıcı teknolojisi; tıp, gastronomi, mühendislik, imalat, sanat ve eğitim gibi sürekli büyüyen farklı uygulama alanlarıla araştırmaciların, endüstrinin ve tüketicilerin büyük ilgisini çeken, gelişmekte olan dijitalleştirilmiş bir teknolojidir. Farklı sektörlerde uygulama alanı bulunmasına karşın kompleks uygulamaları gastronomi alanında ortaya çıkmaktadır. Başka bir ifade ile son çalışmalarda 3D yazıcı teknolojisinde araştırmacıları harekete geçiren trend alanı "gıda sektörü" olarak karşımıza çıkmaktadır. Gıda sektöründe katmanlı üretim teknolojisi tüketiciye özel lezzet, maliyet, beslenme kriterlerine uygun olan tüketime hazır bir ürün sunmaktadır. Bu derleme; gida endüstrisinde 3D yazıcı teknolojisinin önemini ortaya koymakta, 3D model oluşturma ve dilimlemeden oluşan gıda yazıcı sisteminin ilk adımını özetlemektedir.

Anahtar kelimeler: 3D yazıc1, katmanlı üretim, teknoloji, gıda.

\section{THREE-DIMENSIONAL (3D) PRINTING TECHNOLOGY FOR CUSTOMIZATION AND ELABORATION OF FOOD}

\begin{abstract}
Three-dimensional (3D) printing technology offers great flexibility in the fabrication of objects with highly complex geometries, allowing intriguing functionalities previously inaccessible. Also referred to as additive manufacturing-(AM) or rapid prototyping, 3D printing is a developing digitized technology that has attracted great interest from researchers, industry, and consumers with its various ever-growing application areas, which include medicine, gastronomy, engineering, manufacturing, arts, and education. Although it has found use in different sectors, the area that has recently activated researchers in 3D printing technology is the "food sector". AM technology offers a ready-to-consume product that is tailored to the consumer, and complies with their taste, cost, and nutritional criteria. This review outlines the importance of 3D printing systems in the food industry, and it summarizes the first step of food printing, which comprises of 3D model building and slicing.

Key words: 3D printer, additive manufacturing, technology, food.
\end{abstract}

\footnotetext{
* Yazışmalardan sorumlu yazar / Corresponding author

凹:hilal.meral@gop.edu.tr 熘: (+90) $3562521616-2889$

且: (+90) 3562521729
}

Hilal Meral; ORCID no: 0000-0001-6238-7958

Aslıhan Demirdöven; ORCID no: 0000-0003-1246-9132 


\section{GİRIŞ}

Günümüzde bilim ve teknolojide meydana gelen gelişmeler ile birlikte farklı teknolojilerin gida sektöründe kullanımına dair çalışmalar hız kazanmıştır. Tüketicinin istek ve ihtiyaçları doğrultusunda, kişiye özel yeni gıda ürünleri üretimini amaç edinen "gida tasarımı" olgusu son yıllarda yenilikçi teknolojilere olan gereksinimi artırmıştır. Bu kapsamda ortaya çıkan gıdalarda 3D yazıcı teknolojisi, çeşitli ürünlerin daha hassas, özgün, inovatif yapı ve tekstürlere sahip ürünlerin oluşumunda uygun bir proses imkanı sunmaktadır. Çeşitli gıda bileşenlerinin ve lezzetlerinin tamamen farklı bir yolla integrasyonuna zemin hazırlayan 3D yazıc1 teknolojisi hem ev kullaniciları hem de tasarımcılar için yenilikçi şekil, tekstür ve lezzet oluşumu sağlayan bir tasarım özgürlüğüdür (Lipton vd., 2015; Aday ve Aday, 2020). Katmanlı üretime veya bilinen diğer adıyla 3D yazıc1 teknolojisine ilk kez 1983 yılında geçilmiş ve hızlı bir şekilde geliştirilerek ürünlerin fiziksel prototiplerinin üretiminde, ürün tasarımlarının işlevsel olarak değerlendirilmesinde, sağlik ürünlerinde yaygin olarak uygulama alanı bulmuştur (Dong vd., 2021).

3D yazıc1 teknolojisi, son yıllarda ileri üretim endüstrisinde esnek ve güçlü bir teknik olarak ortaya çıkmakta ve birçok ülkede yaygin olarak kullanılmaktadır. Gıda sektöründe de büyük bir potansiyele sahip olup karmaş1k geometrik yapılara sahip ürünleri, önceden modelleme tekniği ile özelleştirilmiş objeleri ve özel beslenme içerikleri olan yapıları üretme imkanı sağlamaktadır. 3D yazıcılar keşfedildikten sonra teknik olarak geliştirilerek hem gıdaların üretiminde hem de ambalajlama sektöründe kullanım alanı bulmuştur. İlk kez 1984 yilında Charles Hull tarafindan kullanılmış olan 3D baskı teknolojisi, "Nanotek Instruments" şirketi tarafindan geliştirilerek 2001 yilında özel tasarım pasta üretiminde yararlanılmıştır. 2009 yılında Electrolux Design Lab. yarışmasinda "Kläber" firması birden fazla materyal kullanımına olanak sağlayan "Moléculaire" ad1 verilen bir cihaz tasarımı ile ödül almıs ve 2013 yılında ise Amerika Birleşik Devletleri'nin uzay programı çalışmalarından sorumlu kurum olan Ulusal
Havacillk ve Uzay Dairesi (NASA) tarafindan uzun süreli keşif görevlendirmelerinde kullanılmak üzere özel 3D gıda yazıcılarının tasarımına yönelik çalışmalar hız kazanmıştır. Ürünlerin bileşimi bazında irdelendiğinde, bu teknolojinin kullanımına dair ilk örneklerde, şeker, nişasta, maya, misır şurubu ve şeker hamuru karışımından oluşan hamurun ekstrüzyonu yapılmışıtı (Lille vd., 2018). Konu ile ilgili yapılan araştırmalar ilerledikçe, seçici lazer sinterleme teknolojisi ile şeker taneciklerinin ergimesi için lazer 1şınları geliştirilerek çikolata ve peynir gibi çeşitli ürünlerin üretiminde de 3D yazıc1 teknolojisinden yararlanılmaya başlanmıştır (Zoran vd., 2011; Mantihal vd., 2017; Mantihal vd., 2019). Son yıllarda ise 3D gida baskisinin gelecek nesiller için bir "yazdır-ye" (print-and-eat) teknolojisi olarak sektörde önemli bir yer alacağ1 öngörülmektedir (Aldanmaz vd., 2017; Prakash vd., 2019).

$\mathrm{Bu}$ derlemenin amac1; 3D yazıc1 teknolojisinin pazardaki yerini ve potansiyel uygulamalarını inceleyerek gıda sektöründe müşteri ihtiyaçlarını hangi düzeyde karşıladığını, gıda ve gastronomi alanına ne gibi katkılar sağladığını anlamak için 3D yazıcı sisteminin önemine, proses aşamalarına ve kullanım alanlarına ilişkin bilgileri ortaya koymaktır.

\section{Gıda Sektöründe 3D Yazıcı Teknolojisi Neden Önemli?}

Gıda sektörü için hızlı prototipleme teknolojisinin, tüketiciye özel, lezzet, maliyet, beslenme kriterlerine uygun ve tüketime hazır bir ürün sunarak gida işlemede yeni sinırlar belirleyeceği düşünülmektedir (Deloitte, 2015). Bu duruma ek olarak teknoloji, mucitlerin kendi düşüncelerini oluşturma noktasında engel oluşturan kaynak ve yetenek yetersizliklerinin giderilmesini sağlayarak tasarımcılara yeni bir kap1 aralamakta ve "İnovasyonun Demokratikleşmesini” sağlamaktadır. $\mathrm{Bu}$ nedenle, gidalar fizyokimyasal özellikleri ile geniş varyasyonlara sahip karmaşık sistemler olmasına rağmen, araştırmacılar 3D baskının çeşitli gıda ürünlerine uygulanmasını yaygınlaştırmak için çok çeşitli çalışmalar gerçekleştirmektedir (Lipton vd., 2010; Tess, 2016). 
Gıda sektöründe 3D yazıcı teknolojisi gıdanın bileşimini, yapısını veya yoğunluğunu farklı yaş, cinsiyet ve meslekteki tüketicilerin tercih ve ihtiyaçlarına göre ayarlayarak beslenme düzenlerine tam olarak uyumlu geniş bir yelpaze sunmaktadır. Böylece her tüketici için kişiselleştirilmiş birbirinden farklı gıda ürünleri meydana getirilmekte ve ayırt edilebilir gida olarak pazarda yerini almaktadır. Bu gida ürünlerinin çoğunun üretimi ve dizaynında özel zanaatkarlara ve fabrikasyonunda çok yüksek maliyetlere ihtiyaç duyulmaktadır. Bu noktada 3D yazıcı teknolojisi, mutfak sanatları ile profesyonel olmayan gida zanaatkarları arasinda bir köprü görevi görmektedir (Simon, 2015).

3D yazıc1 sistemi, birden fazla adımı hatta tüm gida üretim sürecini değiştirerek kitlesel özelleştirme maliyetini azaltmakta ve bu süreçte meydana gelebilecek personel hatalarını minimize ederek üretim verimliliğini arttırmaktadır (Simon, 2015; D'Angelo vd., 2016). 3D g1da yazicilar1 ayrıca çeşitli gıda bileşenlerinin ve lezzetlerinin tamamen farklı bir yolla bütünleşmesine zemin hazırlamaktadır. Bucosini gibi bazı şirketler 3D gida yazıc1 teknolojisi için reçetelerini ve bileşenlerini paylaşarak kendi pazar yerlerini oluşturmuşlardır (Molitch-Hou, 2015). Bu şirkete ek olarak Hollanda Uygulamalı Bilimsel Araştırma Örgütü, geleneksel gida maddelerinin yerine farklı bileşenlerin kullanımı ile yeni gıda ürünlerinin oluşumu için araştırma yapmaktadır. Alternatif bileşen olarak alg, böcek, mantar veya acı bakla tohumlarından yararlanarak elde edilen protein ile lezzetli ve besleyici yeni gıda ürünleri meydana getirilmiştir. $\mathrm{Bu}$ anlamda 3D gida yazıcıları, görünüm olarak tüketici için tüketilmesi daha zor olan ham maddelere kullanım imkanı sağlamaktadır (Peppel, 2015; Sun vd., 2015b; Izdebska ve Zolek, 2016).

Katmanlı üretim, daha az hammadde ve daha az enerji kullanımı ile ekolojik ayak izinin azaltılmasını sağlamaktadır. Gıdalarda 3D yazıc1 teknolojisi, işleme sırasında birden çok adımı tek adımda birleştirebilen etkili bir sistem olduğu için oluşan atık miktarının azalmasını sağlamakta ve komut verilmedikçe gıda üretimi gerçekleşmediği için sistemde daha az su ve enerji tüketimi söz konusu olmaktadır. $\mathrm{Bu}$ anlamda 3D yazıc1 teknolojisi, enerji tasarrufu sağlayan teknolojiler içerisinde yer almakta ve bu durum sektörde kullanımının yaygınlaşmasında önemli bir rol oynamaktadır (Shahbazi ve Jäger, 2020).

3D gıda yazıcı teknolojisi, gıda tedarik zincirinde atık miktarının azaltılması ve artıkların değerlendirilmesini sağlayan bir sistemdir. Bu anlamda teknoloji kullanımı ile su, enerji ve gıda maddelerinin israfı önlenmektedir. Hollanda'da Upprinting Food şirketi bayat ekmek, ezilmiş meyve ve sebzeleri, restoranlarda artan gidaları 3D yazıc1 teknolojisinde materyal olarak değerlendirerek atıştırmalık ürün elde etmiştir (Boissonneault, 2019). Bu durumlar göz önüne alındığında aslında çevre dostu ve sürdürülebilir bir teknoloji olduğu görülmektedir. Yiyeceklerle bilgi aktarımı bir zenginlik ortamı yaratmakta ve üzerlerinde tanıtım için iş logoları basılı kek, çikolata, kurabiye gibi ürünler sosyal bağ1 güçlendirmektedir (Dankar vd., 2018a).

50 yaşın üzerindeki insanların yaklaşık \%25'i çiğneme ve yutma problemi yaşamaktadır. Bu problemi yaşayan kişiler daha yumuşak tekstüre sahip veya püre haline getirilmiş görünüş, lezzet ve tekstür özellikleri dikkate alındığında çok da iştah açıcı olmayan gıdaları tercih etmek zorunda kalmaktadır. Yaşlı insanlar için yumuşak, yenilikçi tekstüre sahip besleyici gıda üretimini sağlama noktasında Uygulamalı Bilimsel Araştırmalar Kurumu (TNO, Hollanda), püre haline getirilmiş yiyecekleri esnek bir tasarım derecesiyle basmayı amaçlayan "Performans" adlı bir proje başlatmıştır. Uygulamalı Bilimsel Araştırmalar Kurumu, antreman sonrasi tüketilmek üzere sporcular ve atletler için protein, yağ, vitamin, diyet lifleri, fitokimyasallar gibi besin ögelerinin dengeli şekilde vücuda alınması için uygun formülasyonların elde edilmesi amaciyla yazıcı teknolojisinin kullanımını önermektedir (de Roos, 2013; Lille vd., 2017). Ayrıca, özellikle yutma güçlüğ̈ çeken hastaların günlük diyetlerindeki protein gereksinimlerini karşılanmasında et ve et ürünleri önemli bir yere sahiptir. Et ve et ürünleri yapısal olarak sert özelliktedir. Bu nedenle, 3D yazıcılarda kullanılması pratikte çok uygun değildir. Ancak, etin yapisinda uygulanan 
değişimlerle, çeşitli formülasyonlarda kullanılmakta (3D yazıcılarda) ve böylece hem yutma güçlüğü çeken bireylerin tüketebileceği hale getirilebilmekte hem de ürünlerin hayvansal besinsel açıdan zenginleştirilmesi mümkün olmaktadır. Et sert bir yapiya sahip olmasina rağmen 3D yazıc1 sisteminde formülasyonu bileşiminde yapis1 modifiye edilerek yutma güçlüğü çeken bireylerin tüketebileceği hale getirilebilmektedir (Arsava vd., 2018; Dick vd., 2019). Gıda maddelerinin özelleştirilmesinde yararlanılabilecek bir diğer tüketici grubunu çocuklar oluşturmaktadır. Eğitim araçları olarak da kullanılabilecek 3D gida yazıciları ile elde edilen sağlıklı besleyici atıştırmalıklar, yenilikçi şekillerle çocukların tüketmeye daha istekli olmalarını sağlayabilecektir. Meyve-sebze tüketimini teşvik etmek amaciyla çocuklar için özelleştirilmiş bir gida formülasyonu olarak meyve bazlı atıştırmalık geliştirilmiştir (Hamilton vd., 2018; Derossi vd., 2018).

Gıda İşlemede 3D Yazıcı Teknolojisi Proses Aşaması

3D yazıc1 teknolojisi, bir ürünün 3D bilgisayar tasarım programından veya bazı çevrimiçi hizmetlerden (Thingiverse, Shapeways, Ponoko veya Sculpteo vb.) yararlanilarak gidanin katmanlar halinde oluşturulduğu kontrollü bir süreçtir. $\mathrm{Bu}$ süreçte 3 boyutlu model oluşturulduktan sonra tasarım bilgileri yazıcıya gönderilmekte ve modeli katmanlara bölmektedir. Ardından bu katmanlar, belirlenen 3 boyutlu kesit modelinde birleştirilmektedir (Michaeli vd., 2017).

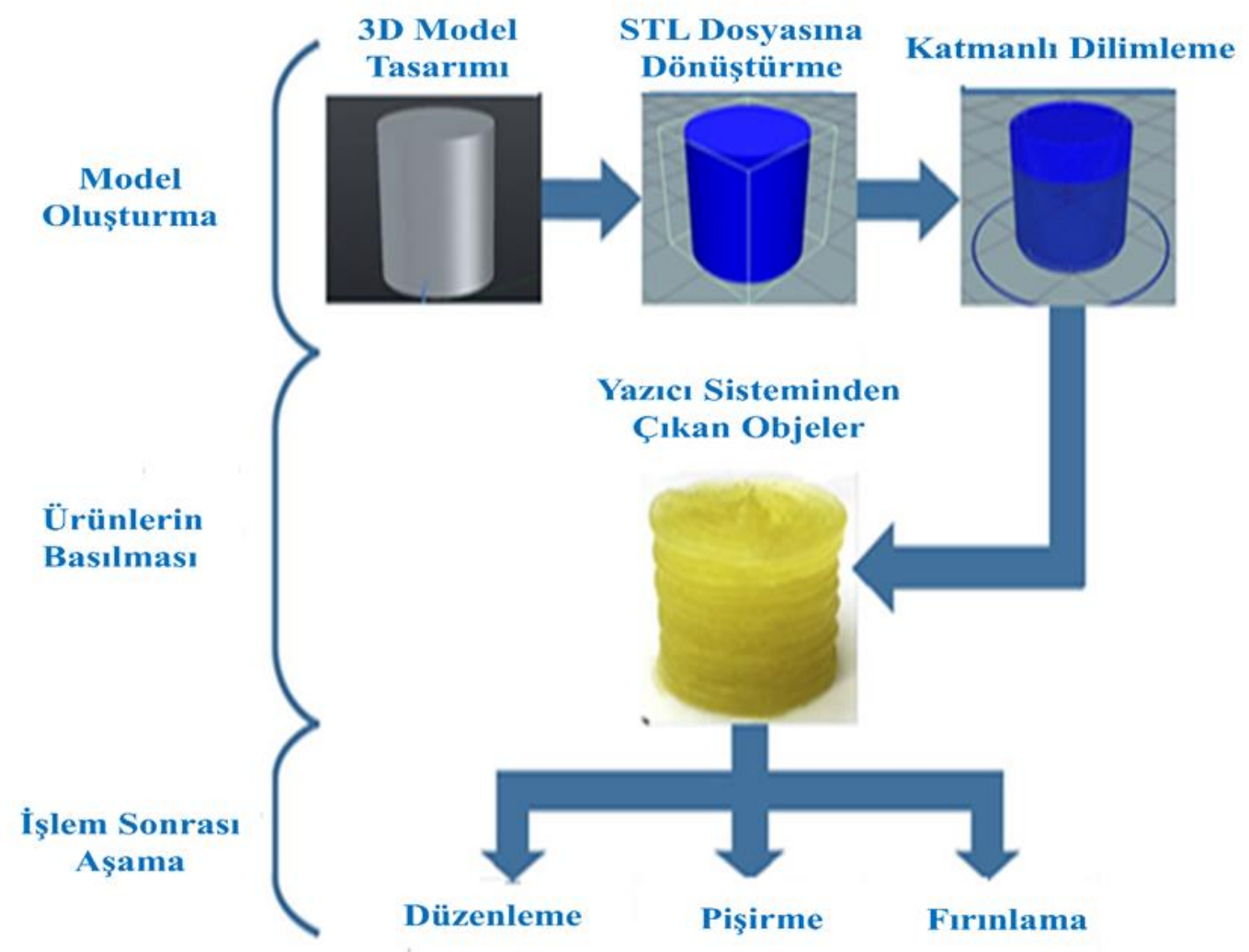

Şekil 1. (A) 3D g1da bask1 sürecinin şematik diyagramı (Guo vd., 2019) 


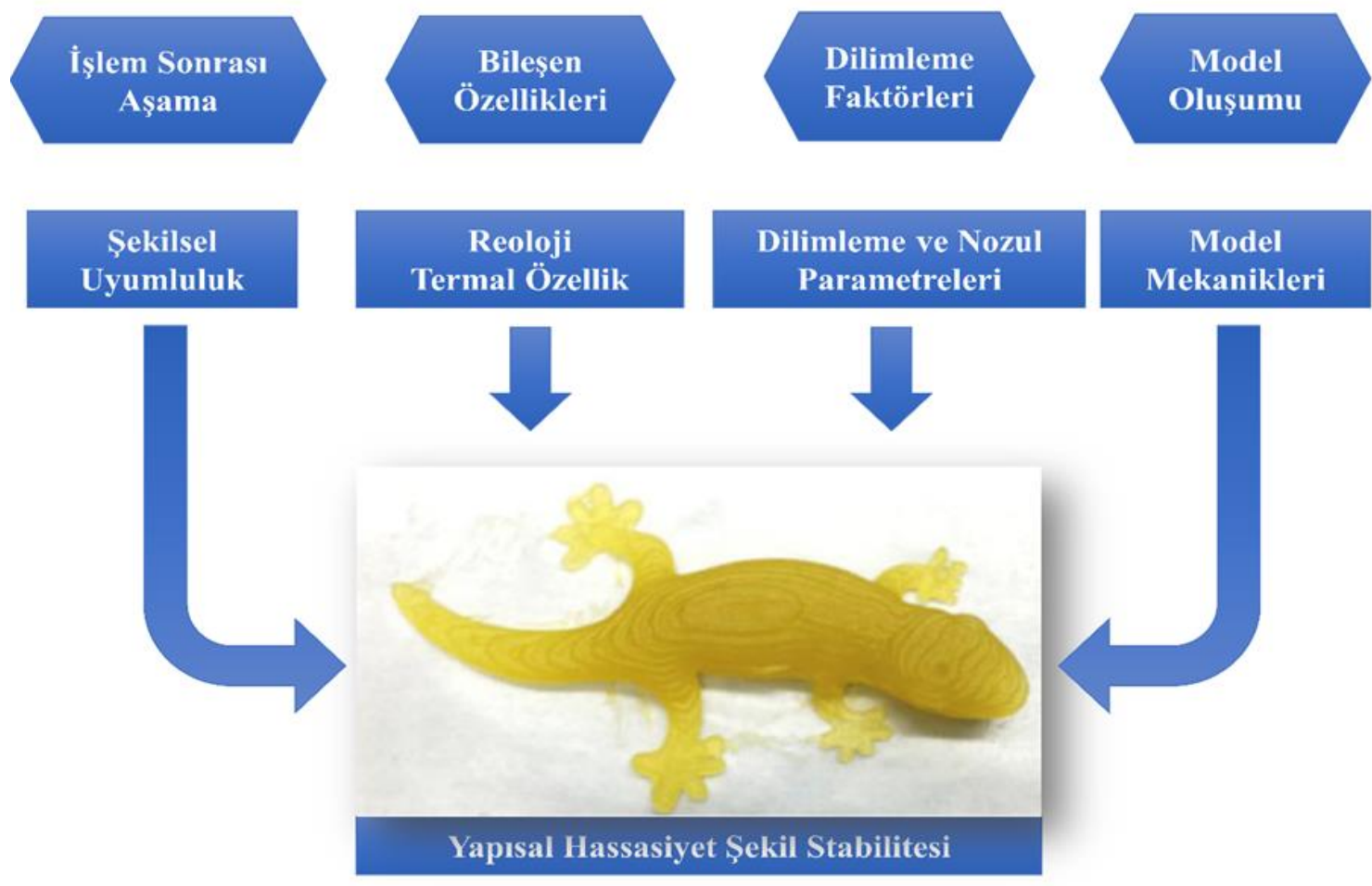

Şekil 1. (B) 3D baskı teknolojisinin iş akışının şematik diyagramı (Guo vd., 2019)

Şekil 1-A'da da görüldüğgu gibi gıdalarda 3D yazıcı sisteminde proses aşaması 3 adımdan oluşmaktadır:

- 3D model oluşturma

- Ürünlerin basilması

- İşlem sonrası aşama

3D model oluşturma, modelin bilgisayar destekli çizim programı (CAD) ile tasarlanmasını, tasarlanan modelin STL (stereolitografi) dosyasına dönüştürülmesini içeren bir prosestir. Tasarlanan modelin 3D yazıcı için anlaşılabilir hale getirilmesi için STL formatındaki dosyanın bir tür nümerik kontrol (NC) programlama dili olan G-kodu dosya formatına dönüştürülmesi gerekmektedir. $\mathrm{Bu}$ dönüşüm için dilimleme yazılım programlarından yararlanılmaktadır (Godoi vd., 2016; Michaeli vd., 2017). Dilimleme yazılımı, 3D model ile 3D yazıcı arasındaki proses güzergâh planlaması ve bu proses bölümlerinin hareket adımlarının hesaplanmasinda bir ara sürücü konumundadır. Dilimleme yazılımı sonucunda oluşturulan bilgilerin yazıcıya aktarılmasıyla her bölümün ana hatlarını elde etmek için model katmanlar halinde dilimlenmektedir. Dilimlenen katmanların tasarlanan 3D model kapsamında biriktirilmesiyle üç boyutlu nesneler oluşturulmaktadır. Son olarak yazıcıdan geçirilmiş objeler tasarlanmak istenen ürünün özelliğine bağlı olarak kırpma, pişirme veya firınlama işlemlere tabi tutulabilmektedir (Ötleş, 2016; Candoğan ve Bulut, 2021).

3D yazıcı teknolojisi kullanımını daha zor hale getiren en önemli parametreler; kullanilan 3D model şekli, dilimleme parametreleri, bileşenlerin akış hızı ve işlem sonrasındaki koşullar gibi faktörlerden etkilenen yapisal hassasiyet ve şekil stabilitesi olarak karşımıza çıkmaktadır (Şekil 1-B). Yazıcı sisteminden geçirilmiş ürünlerin yapısal 
doğruluğunda gida bileşenlerinin reolojik, termal ve kimyasal özellikleri kritik öneme sahiptir. Yazıciların tasarım parametreleri ve kullanilan malzemelerin özelliklerinin yanı sıra, dilimleme yazılımındaki parametre ayarları da elde edilecek ürünlerin baskı hassasiyeti ve yapısal özelliklerini etkilemektedir. Bunun yanında basım yüksekliği, nozül yarıçapı, yazıcı hızı, nozül hareket hızı, katman kalınlığ1 ve sıcaklık gibi proses faktörleri yazıcı sisteminden çıkan son ürünün kalitesi için oldukça önemlidir (Dankar vd., 2018a). İşlem sonrasinda kurutma ve firnnlama gibi deformasyona neden olan uygulamalar, elde edilen ürünün şekil stabilitesinin düşmesine neden olabilmektedir. Tüm bu faktörler, 3D model tasarımının yazıcı işlemine tabi tutulmuş son ürünlerin kararlıllğını ve hassasiyetini belirleyebilen veya etkileyebilen ilk ve kritik bir adım olduğunu kanıtlar niteliktedir. İyi bir tasarım model, kullanılan üç boyutlu yazıcı, gıda mürekkepleri ve basım sonrası işlem parametrelerine uygun olmalı ve tüketici beklentilerini karşılamalıdır (Yang vd., 2017).

Gıdalarda 3D yazıc1 teknolojisinde hangi işlemin kullanılacağını belirlemenin anahtarı, basılan malzemelerin yapısı ve çeşididir. Her biri kendine özgü yap1, işlenebilirlik ve yapışma kombinasyonuna sahip monomer ve polimerlerden oluşan çok sayıda farklı gida materyali mevcuttur. Hidrojel, yumuşak peynir, humus ve çikolata gibi yazılabilme özelliğine sahip maddeler bir enjektör yardımı ile pürüzsüzce ekstrüde edilebilmekte ve prosesin ardından ekstra herhangi bir son işleme gerek duyulmaksızın şekillerini stabil olarak koruyabilmektedir. Buna karşıllı pirinç, et, meyve ve sebze gibi yiyecekler doğası gereği $3 \mathrm{D}$ yazıcıda basılamamaktadır. Bu gibi kat1 ve yarı katı formdaki bazı gıdalar çeşitli ön işlemlerle (enzim ilavesi, hidrokolloidlerin kullanımı vb.) modifiye edilerek yazdırılabilir hale dönüştürülebilmektedir (Değerli ve El, 2017; Kim vd., 2017; Chuanxing vd., 2018; Dankar vd., 2018b).

\section{D Gıda Yazıcı Sisteminde Kullanılan Teknolojiler}

3D gida yazıcılarında kullanılan bask1 teknolojisinin tercih edilmesinde, gıdanın bileşimi ve tekstürel yapısı, kullanım kolaylı̆ğ, düşük maliyet gibi faktörler kullanılacak yazıcının tercihinde etkin rol oynamaktadır. Ekstrüzyon yoluyla doğrudan bask1, mürekkep püskürtmeli, sıcak hava yoluyla seçici sinterleme teknolojisi, bağlayıc1 püskürtme 3D gida baskisinda yaygin olarak kullanılan teknolojilerdir (Liu vd., 2017). Ekstrüzyon yoluyla doğrudan bask1 teknolojisi, çikolata, jelatin, şeker gibi sıcaklık uygulandığında akışkan forma geçebilen gıdaların, püre, jel ve hamur halindeki materyallerin basıminda kullanılabilmektedir. Çok çeşitli yiyeceklerin basılmasında kullanılmakta olup doğrudan yazdirllamayan gidalara ksantan gam, jelatin, gam arabik, karragenan vb. hidrokolloidlerin ilavesi ile ürün yapısı desteklenerek yazdırılabilir hale getirebilmektedir (Yang vd., 2015). Ekstrüzyon yoluyla baskı teknolojisinde üretim süresinin uzun olması ve tabakalar arasında katman çizgisinin oluşması sistemin dezavantajıdır. Mürekkep püskürtmeli yazıcı teknolojisi ise genellikle düşük viskoziteli materyalleri basımında kullanılmaktadır. Dekorasyonda yenilikçi şekillerin oluşumunda kolay uygulanabilir bir yöntem olmakla beraber karmaşık gıdaların baskısında kullanılamaması bir dezavantaj oluşturmaktadır (Liu vd., 2017).

Sıcak hava yoluyla seçici sinterleme teknolojisinde ürün bileşiminde yer alan toz formdaki partiküllerin bir alanda toplanmakta ve toplanan bu partiküllerin $1 s 1$ kaynağ kullanımı ile erimesi ve kaynaşması sağlanmaktadır. Is1 kaynağ1 olarak sıcak hava veya lazer ışınları kullanılabilmektedir. Kullanılan 1sı kaynağına bağlı olarak seçici sıcak hava yoluyla seçici sinterleme teknolojisi veya seçici lazer sinterleme teknolojisi olarak isimlendirilmektedir. Sinterleme teknolojisinde işlem süresi kısa olmakla beraber bazı işletmelerde toz partiküllerin geri dönüşümü de sağlanabilmektedir. Düşük erime noktasına sahip sinırlı sayıda gida materyallerine uygulanabilmesi nedeniyle kullanımı kısıtlıdır (Godoi vd., 2016). Bağlayıc1 püskürtme teknolojisi, sinterleme teknolojisi ile benzer olmakla beraber bu sistemde farklı olarak ürün bileşiminde yer alan toz partiküllerin kaynaşmasında 1sı kaynağı kullanımı yerine bağlayıcı bir ajan kullanılmaktadır. Bağlayıcı püskürtme teknolojisi, hızlı imalat ve düşük 
maliyet gibi avantajlar sağlamakla birlikte, üretilen ürünün yüzeyinin pürüzlü olması ve yüksek makine maliyeti gibi dezavantajlara da sahiptir. Bu teknoloji ile kompleks yapılara sahip gidalar üretilebilmekte, ancak elde edilen ürünlerin besin değeri daha düşük, şeker içeriği ise yüksek olduğu için diyabet, obezite ve kalp hastalığ ile ilişkilendirildiğinde sağllk için tehdit oluşturmaktadır. Ayrıca elde edilen son ürünler
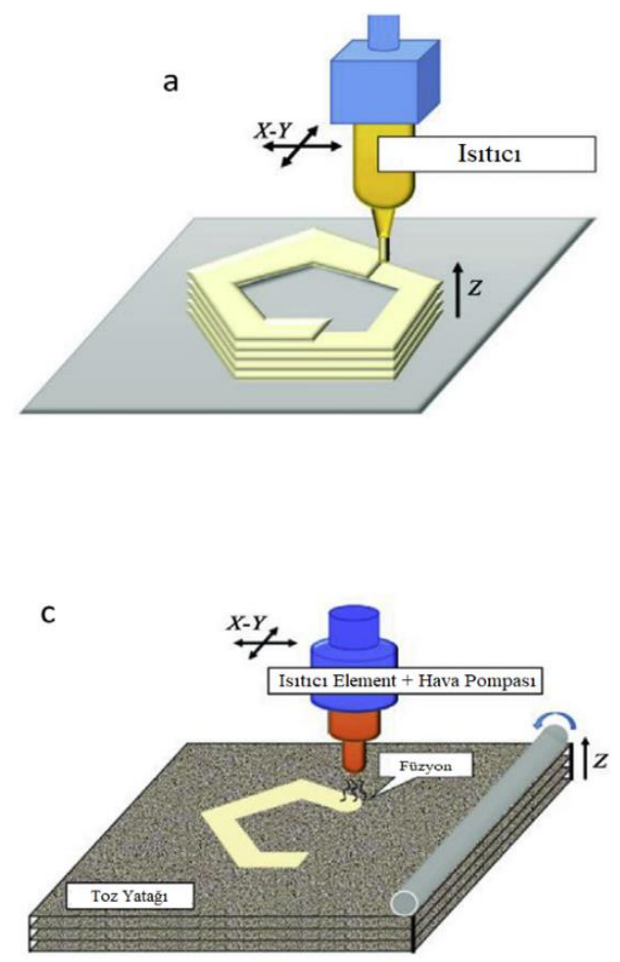

kırılgan yapıda olduğu için şekillerini uzun süre koruyamamaktadır (Dankar vd., 2018; Candoğan ve Bulut, 2021).

Gida materyallerine uygulanan farklı 3D yazıcı teknolojileri Şekil 2'de, bu teknolojilerin çalışma prensipleri, olumlu ve olumsuz yönleri Çizelge 1'de verilmiştir.
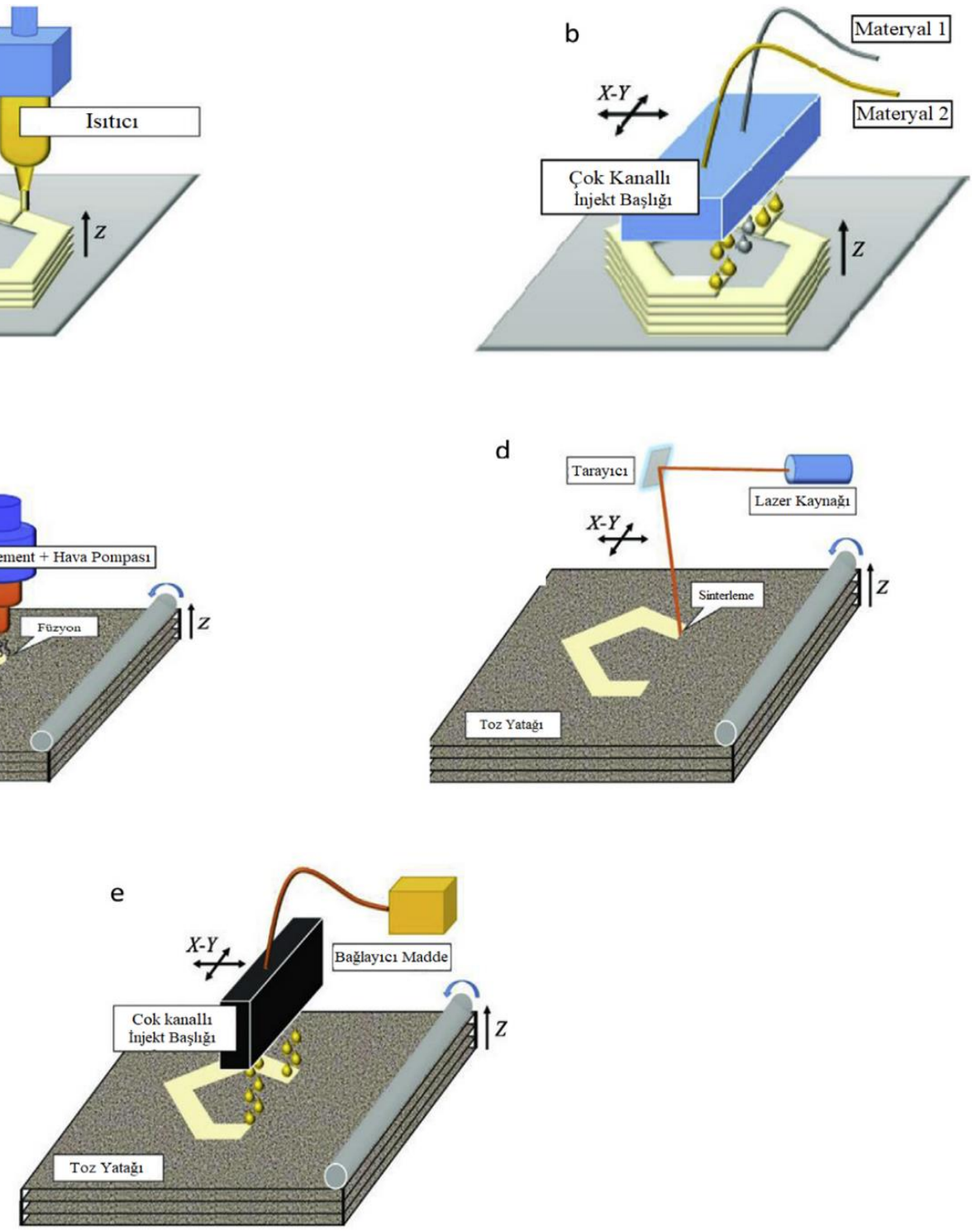

Şekil 2. Gıdalarda 3D yazıcı sisteminde uygulanan farklı teknolojilerin şematik gösterimi (a) Ekstrüzyon Yoluyla Doğrudan Baskı (b) Mürekkep Püskürtmeli (c) Sicak Hava Yoluyla Seçici Sinterleme (d) Seçici Lazer Sinterleme (e) Bağlayıcı Püskürtme (e) (Sun ve ark., 2015a; Tan vd., 2018) 
Çizelge 1. 3D yazıcı sistemi teknolojilerinin karşılaştırılması (Dankar vd., 2018a)

\begin{tabular}{|c|c|c|c|c|c|}
\hline $\begin{array}{l}\text { Yazıc1 } \\
\text { Teknolojisi }\end{array}$ & Prensip & Ürünler & Avantajları & Dezavantajları & Referans \\
\hline $\begin{array}{l}\text { Ekstrüzyon } \\
\text { Yoluyla } \\
\text { Doğrudan } \\
\text { Bask1 }\end{array}$ & $\begin{array}{l}\text { Bir nozul } \\
\text { başlı̆̆ından } \\
\text { ekstrüzyon } \\
\text { işleminin } \\
\text { gerçekleşmesi } \\
\text { ve katmanlar } \\
\text { halinde } \\
\text { biriktirilmesi }\end{array}$ & $\begin{array}{l}\text { Çikolata, } \\
\text { peynir, püre } \\
\text { pizza, } \\
\text { humus, } \\
\text { kurabiye } \\
\text { hamuru, } \\
\text { fistık ezmesi }\end{array}$ & $\begin{array}{l}\text { Çok çeşitli yiyecekleri } \\
\text { destekleme } \\
\text { Gıdalarda sonsuz } \\
\text { kombinasyonlara ve } \\
\text { serbestlik derecesine } \\
\text { izin vermesi } \\
\text { Birden fazla nozul ile } \\
\text { birleştirilebilmesi }\end{array}$ & $\begin{array}{l}\text { Katmanlar } \\
\text { arasında dikiş } \\
\text { çizgisinin } \\
\text { görünümü } \\
\text { Uzun proses } \\
\text { süresi }\end{array}$ & $\begin{array}{l}\text { Yang vd., } \\
\text { 2015; } \\
\text { Severini vd., } \\
\text { 2016; } \\
\text { Lanaro vd., } \\
\text { 2017; } \\
\text { Severini vd., } \\
2018\end{array}$ \\
\hline $\begin{array}{l}\text { Mürekkep } \\
\text { Püskürtmeli } \\
\text { Yazıcı }\end{array}$ & $\begin{array}{l}\text { Şırınga } \\
\text { nozulünden } \\
\text { üretilmek } \\
\text { istenen ürüne } \\
\text { püskürtme } \\
\text { yapılması }\end{array}$ & $\begin{array}{l}\text { Şekerleme } \\
\text { kurabiye, } \\
\text { cupcake, } \\
\text { bisküvi } \\
\text { üzerine } \\
\text { dekoratifler, } \\
\text { pizza }\end{array}$ & $\begin{array}{l}\text { Kolay uygulanabilir } \\
\text { Dekorasyonda } \\
\text { yenilikçi şekillerin } \\
\text { oluşumu }\end{array}$ & $\begin{array}{l}\text { 2D görüntü } \\
\text { oluşumu, } \\
\text { Dekorasyonda } \\
\text { yüzey } \\
\text { dolgusunda } \\
\text { kisıtlı uygulama }\end{array}$ & $\begin{array}{l}\text { Holland vd., } \\
2018\end{array}$ \\
\hline $\begin{array}{l}\text { Sinterleme } \\
\text { Teknolojisi } \\
\text { (Sicak } \\
\text { hava/Lazer) }\end{array}$ & $\begin{array}{l}\text { Toz } \\
\text { partiküllerin } \\
\text { erimesini ve } \\
\text { kaynaşmasını } \\
\text { sağlayan 1sı } \\
\text { kaynağ1 } \\
\text { kullanımı } \\
\text { (sıcak hava veya } \\
\text { lazer 1şınları) }\end{array}$ & $\begin{array}{l}\text { Şekerli } \\
\text { g1dalar } \\
\text { Nesquik } \\
\text { tozu }\end{array}$ & $\begin{array}{l}\text { Kısa işlem süresi } \\
\text { Tozların geri } \\
\text { dönüşümü, } \\
\text { Kompleks gıda } \\
\text { maddelerinin } \\
\text { üretiminde işlem } \\
\text { kolaylığı }\end{array}$ & $\begin{array}{l}\text { Düşük erime } \\
\text { noktasına sahip } \\
\text { sinırlı sayıda gida } \\
\text { materyallerine } \\
\text { uygulanması }\end{array}$ & $\begin{array}{l}\text { Godoi vd., } \\
2016\end{array}$ \\
\hline $\begin{array}{l}\text { Bağlayıcı } \\
\text { (Yapıştırıcı) } \\
\text { Püskürtme }\end{array}$ & $\begin{array}{l}\text { Toz } \\
\text { partiküllerin } \\
\text { erimesi ve } \\
\text { kaynaşmasını } \\
\text { sağlayan } \\
\text { bağlayıcı bir } \\
\text { ajan kullanımı }\end{array}$ & $\begin{array}{l}\text { Toz şeker, } \\
\text { un, nişasta } \\
\text { içerikli } \\
\text { materyal } \\
\text { kullanımı ile } \\
\text { hamur eldesi }\end{array}$ & $\begin{array}{l}\text { Kompleks yapıların } \\
\text { oluşumu, } \\
\text { Hataların minimum } \\
\text { seviyede tutulduğu bir } \\
\text { teknoloji }\end{array}$ & $\begin{array}{l}\text { Nihai ürünler } \\
\text { kırılgan yapıda } \\
\text { olması nedeni ile } \\
\text { uzun muhafaza } \\
\text { koşullarına } \\
\text { uygun olmaması }\end{array}$ & $\begin{array}{l}\text { iReviews, } \\
\text { 2014; } \\
\text { Warner vd., } \\
2019\end{array}$ \\
\hline
\end{tabular}

3D Gida Yazıc1 Teknolojisi Uygulama Alanları

Beslenme yönünden kişiye özgü ürünlerin tasarlanması için kullanılan 3D yazıcı teknolojisinde, spesifik şekil ve iç yapılara sahip özel tasarlanmış modellere ihtiyaç duyulmaktadır (Rayna ve Striukova, 2016; Vancauwenberghe vd., 2017). Bu kapsamda farklı tüketici grupları ve alanlara yönelik yararlanılan spesifik alanlar Çizelge 2'de özetlenmiştir.

\section{Askeri Alanlarda Yapılan Çalısmalar}

3D yazıcı teknolojisi ile elde edilen gıda ürünleri, son derece özelleștirilebilir ve uzun raf ömrüne sahip olmasi nedeniyle Amerikan ordusu tarafindan ilgi odağı haline gelmiştir. Askeri personelin sırtlarında taşıdıkları yükü azaltmak için, tasarlanan gida modellerinin yüksek dolgu yüzdesine sahip ve daha sıkı yapı özelliklere sahip olmas1 önemlidir. Ultrasonik aglomerasyon kombinasyonuna sahip 3D yazıcı teknolojisi ile elde edilen ürünlerin partikülleri ultrasonik dalgaların kullanımı ile birbirine kaynaştırılmakta ve partiküllerin birleşmesi sağlanabilmektedir (Liu vd., 2017).

\section{Uzay Alanında Yapılan Çalısmalar}

Günümüzde var olan gida sistemleri, raf ömrü ve besin kayıpları düşünüldüğünde uzun süreli görevlendirmelerde ihtiyaçları karşılayamamaktadır. Uzay aracında katmanlı üretimi temel alan yazıcı teknolojisi ile astronotlar 
için çok farklı gıda bileşenleri kullanımı söz konusu olmakta ve çok farklı geometrik şekillere sahip gidalar üretilebilmektedir. Ulusal Havacılık ve Uzay Dairesi (NASA), uzun vadeli keşif görevleri sürecinde güvenlik, kabul edilebilirlik, çeşitlilik ve beslenme kararlılı̆̆1 yönünden ihtiyaçlarını karşılayan ve minimum uzay aracı kaynaklarının kullanımıyla en kısa sürede üretimi gerçekleştirilebilecek bir gida geliştirme noktasinda 3D gida yazicilarindan yararlanmaktadır. Uzay aracında katmanlı üretimi temel alan yazıcı teknolojisi ile astronotlar için çok farklı gıda bileşenleri kullanımı söz konusu olmakta ve farklı tekstürlere sahip gidalar üretilebilmektedir (Nasa, 2013).

Çizelge 2. Farklı alanlarda gıda yazıcı teknolojisine yönelik çalışmalar (Guo ve ark., 2019)

\begin{tabular}{|c|c|c|c|}
\hline $\begin{array}{l}\text { Spesifik Gida } \\
\text { Alanlar1 }\end{array}$ & Alanlardaki Problemler & 3D Yazıcı Fonksiyonu & 3D Model Talepleri \\
\hline Ordu & $\begin{array}{l}\text { Bireysel özelleştirilmiş } \\
\text { yiyeceklere olan ihtiyaç }\end{array}$ & $\begin{array}{l}\text { Özelleştirilebilir ve daha } \\
\text { az yer kaplayan gida } \\
\text { üretimi }\end{array}$ & $\begin{array}{l}\text { Askerlerin sırtlarındaki } \\
\text { yükü azaltma noktasında } \\
\text { dolgu yüzdesinin } \\
\text { arttırılması }\end{array}$ \\
\hline Uzay & $\begin{array}{l}\text { Keşif } \\
\text { görevlendirmelerinde } \\
\text { uzun raf ömrüne ve } \\
\text { besleyici değere sahip } \\
\text { yiyeceklere olan ihtiyaç }\end{array}$ & $\begin{array}{l}\text { Mikro besin } \\
\text { elementleriyle gidaların } \\
\text { yeniden oluşturulması }\end{array}$ & $\begin{array}{l}\text { Raf ömrü uzun ve } \\
\text { minimum uzay aracı } \\
\text { kaynaklarıla üretimi } \\
\text { gerçekleştirilebilecek } \\
\text { modellerin tasarlanması }\end{array}$ \\
\hline $\begin{array}{l}\text { Yapay Doku } \\
\text { Mühendisliği }\end{array}$ & $\begin{array}{l}\text { Hayvansal ürünlere } \\
\text { alternatif gida ürünlerine } \\
\text { olan ihtiyaç }\end{array}$ & $\begin{array}{l}\text { Alternatif gida } \\
\text { bileşenlerinin } \\
\text { integrasyonuna zemin } \\
\text { hazırlamas1 }\end{array}$ & $\begin{array}{l}\text { Vegan veya vejetaryen } \\
\text { tüketici gruplarına } \\
\text { yönelik alternatif ürün } \\
\text { tasarlanması }\end{array}$ \\
\hline $\begin{array}{l}\text { Küçük Yaştaki } \\
\text { Çocukların } \\
\text { Eğitimi }\end{array}$ & $\begin{array}{l}\text { Çocukların merakını ve } \\
\text { beslenme ihtiyaçlarını } \\
\text { karşılamak }\end{array}$ & $\begin{array}{l}\text { Kişiye özel şekil ve } \\
\text { beslenme uyumunun } \\
\text { oluşturulması }\end{array}$ & $\begin{array}{l}\text { Sürdürülebilir bir } \\
\text { sistemin } \\
\text { oluşturulabilmesi için } \\
\text { yenilikçi 3D yazıc1 } \\
\text { sistemi baskı modeli } \\
\text { tasarlanmas1 }\end{array}$ \\
\hline Gastronomi & Hassas görünüm & $\begin{array}{l}\text { Kompleks şekillerin } \\
\text { oluşturulması }\end{array}$ & $\begin{array}{l}\text { Sanatsal dijital model } \\
\text { tasarlanmas } 1\end{array}$ \\
\hline $\begin{array}{l}\text { Şekerleme } \\
\text { Endüstrisi }\end{array}$ & Aroma maddeleri kayıpları & $\begin{array}{l}\text { Aroma kayıplarının } \\
\text { minimum düzeyde } \\
\text { tutulduğu ürünlerin } \\
\text { oluşturulması }\end{array}$ & $\begin{array}{l}\text { Çekirdek malzemenin } \\
\text { salınımını kontrol eden } \\
\text { karakteristik mikro } \\
\text { yapıların tasarlanması }\end{array}$ \\
\hline
\end{tabular}

Yapay Doku Mühendisliği Alanında Yapılan Çalismalar

Yapay doku mühendisliğini 3D yazıcı teknolojisi ile birleștiren yüksek teknolojili bir sistem kullanımı ile de yüksek protein içeriğine ve lifli bir görünüme sahip vejetaryen gida ürünlerin üretimine olanak sağlamaktadır. Vegan ve vejetaryen tüketici grupları, 3D gida yazıcısı ile elde edilen ürünlerin hayvansal gidalara alternatif olarak kullanmayı talep edebilmektedir (Vialva, 2018).

\section{Eğitim Alanında Yapılan Çalışmalar}

Avustralya'nın Sidney şehrinde yer alan Macquarie Üniversitesinde araştırmacılar tarafindan ilköğretim eğitiminde 3D yazıcı ve tasarım sisteminin yararlarını konu alan bir çalışma gerçekleştirilmiş ve elde edilen ön çalışmalar sistemin umut verici olduğunu kanıtlamıştır. 
Konu ile ilgili gerçekleştirilen bir ankette ögretmenlerin geri bildirimlerinin nicel analizi, öğrencilerin 3D baskı ve modelleme kurslarına katılımının \%100'e ulaşabileceğini göstermektedir. 2018 yllında gerçekleştirilen bir çalışmada, bir bakım merkezine yapılan ziyarette eğitim faaliyetleri bazında çocuklara 3D yazıcı teknolojisini öğretmek ve belirli objelerin çocuklar tarafindan daha anlaşılır hale gelmesini sağlamak için ekmek üzerine objelerin resimleri basılmıştır. $\mathrm{Bu}$ şekilde 3D yazıcı teknolojisini kullanımı ile çocuklara yönelik tercihleriyle uyumlu, yeni ve farklı 3D modellerle konuların daha anlaşılır hale gelmesi sağlanmaktadır. Yaş, teknik ve coğrafi kisitlamalara tabi olmayan TinkerCAD ve 3D Slash gibi 3D model oluşturma yazılımları, çocuklar için keyifli bir öğrenme ortamı sunmaktadır (3dslash, 2018; Hamilton vd., 2018).

\section{Moleküler Gastronomi Alanında Yapılan Çalışmalar}

3D yazıc1 teknolojisi, alternatif gida tekstürlerini oluşturma ve yenilebilir sanat eserleri üretme potansiyeline sahip moleküler gastronomi için umut verici bir yöntem olarak karşımıza çıkmaktadır (Türker ve İşleroğlu, 2020). Yenilebilir bir sanat eseri, kompleks geometriye, tekstüre ve lezzete sahip olup benzersiz nesneler üretmek için sanatsal dijital modelin yardımına ihtiyaç duymaktadır. Moleküler gastronomide ekstrüzyon tabanlı 3D yazıc1 sistemi, ters sferifikasyon tekniği ile birleştirildiğinde mutfak sanatı ile katmanlı üretim teknolojisi arasında bir köprü oluşturmaktadır. Teorik olarak, 3D gida yazılım teknolojisi daha uzun süredir ortaya çıkmış olmasına rağmen dünyanın ilk 3D gida bask1 restoranı 2016 yilında Londra'da Food Ink. şirketi tarafindan kurulmuştur (Watkin, 2016; Wiggers, 2017). 2018 yllında ise Byflow şirketinin en iyi şefi ve elçisi ünvanına sahip Jan Smink, Hollanda Walwiga'da yeni 3D yazıcı teknolojisi ile hazırlanan ürünleri servis eden restoranı açmışır (Şekil 3). 3D yazıcı teknolojisinden yararlanan mutfaklar, tamamı önceden tasarlanmış modellerle sanatsal bir görünüme sahip ürünler ile misafirlerin özel bir deneyim kazanmasina olanak sağlamaktadır (Byflow, 2018).
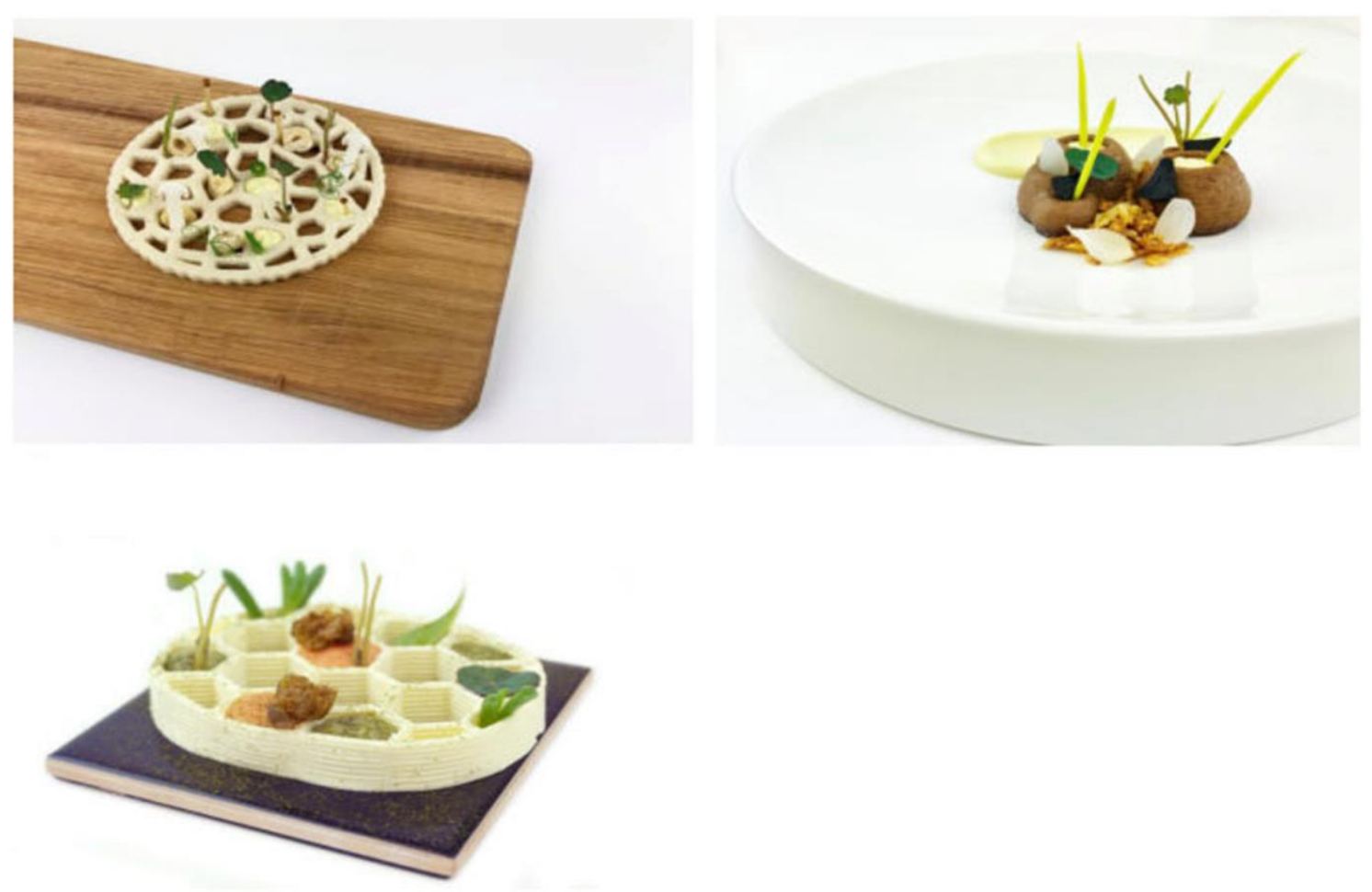

Şekil 3. 3D Yazıcı teknolojisi ile elde edilen ürün görselleri (Byflow, 2018) 


\begin{abstract}
Farmakoloji Alanında Yapılan Çalışmalar
Farmakoloji mühendisliği alanında tablet formunda ilaç üretiminde yararlanılan mikro yap1 metotlarının, çekirdek malzemenin salınımını kontrol etme noktasında avantaj sağlaması nedeniyle 3D yazıcı teknolojisinden yararlanılmaktadır. İlaç üretiminde oluşturulan karakteristik mikro yapıların, uzun süreli, kalıcı ve sabit bir aroma elde etme noktasinda şekerleme üretim proseslerinde kullanımı oldukça dikkat çekicidir (Horst, 2018).
\end{abstract}

\section{Gıda Sektöründe Yapılan Çalışmalar}

Limon suyu jelini üç boyutlu yazıcı teknolojisinde gıda materyali olarak kullanarak şırınga bazlı ekstrüzyon yönteminin optimizasyonunu konu alan bir çalışma gerçekleştirilmiştir. Bu çalışmada ( $\varphi 20 \mathrm{~mm} \times 15 \mathrm{~mm}$ ) boyutlarında bir silindir seçilerek önceden tasarımı oluşturulan dijital 3D modeller online olarak sistemden yüklenmiştir. Gerçekleştirilen çalışmada optimizasyon çalışmaları ile beraber örneklerin yapısal hassasiyetlerinin yükseldiği ve şekil stabilitelerini daha iyi korunduğu tespit edilmiştir (Yang vd., 2018; Pérez vd., 2019). 2018 yilında gerçekleştirilen bir çalışmada baskı materyali olarak işlenmiş peynir kullanılmıştır. $75^{\circ} \mathrm{C}$ de 12 dakika eritildikten sonra, işlenmiş peynir, düşük ve yüksek ekstrüzyon hızlarına göre modifiye edilmiş 3D yazıcı kullanılarak basılmıştır. Çalışmada herhangi bir işlem görmemiş, eritilmiş ve 3D yazıcı ile elde edilen peynirlerin tekstür profil analizi, reolojik analizler, renk analizi ve lazer taramalı konfokal mikroskobu (CLSM) ile elde edilen veriler karşılaştırılmıştır. Eritilmiş ve basılmış peynir numunelerinin her ikisinin de işlem uygulanmayan peynire kıyasla daha yumuşak bir tekstüre sahip olduğu tespit edilmiştir. Gerçekleştirilen çalışma 3D yazıcı teknolojisinin işlenmiş peynirin özelliklerini önemli ölçüde değiştirdiğini ve ürünlerin yapılarını istenilen formülasyona uyarlamak için yeni potansiyel uygulamalar sunduğunu göstermektedir (Le Tohic vd., 2018).

Wang vd. (2018), tarafından gerçekleştirilen çalışmada, 3D yazıcı teknolojisi ile balık surimi jel sistemine dayalı yeni gida yapilarının geliştirilmesini konu almaktadır. Araştırmada sodyum klorür $(\mathrm{NaCl})$ ilavesinin, 3D bask1 malzemesi olarak kullanılan surimi jelin reolojik özelliği, jel dayanımı, su tutma kapasitesi, su dağılımı ve mikro yapısı üzerine etkisi araştırılmıştır. Reolojik çalışmalardan elde edilen sonuçlar, $1.5 \mathrm{~g} \mathrm{NaCl} / 100 \mathrm{~g}$ surimi karışımı ile elde edilen jellerin, 3D yazıc1 sistemi için uygun olduğunu göstermiştir. Elde edilen genel sonuçlar değerlendirildiğinde, surimi jel sistemine dayalı 3D yazıcı teknolojisinin kompleks şekilli gıda matriksleri üretme noktasında umut verici bir yöntem olduğu sonucuna varılmıştır.

Patates nişastası kullanılarak üretimi gerçekleştirilen patates püresinin gida materyali olarak kullanıldığı bir başka çalışmada ise, reolojik özellikleri ve 3D baskı davranışlarında meydana gelen değişimler incelenmiştir. 3D baskı ile üretim esnasında, formülasyon ve işlenebilirlik arasındaki ilişki kurulmuştur. Patates nişastası içermeyen püre örneklerinin düşük akma gerilimine (195.90 $\mathrm{Pa}$ sahip olduğu ve basilı nesnelerde deformasyon meydana geldiği tespit edilmiştir. Püre örneklerine $\% 2$ oranında patates nişastası ilavesi ile ideal ekstrüzyon ve yazıc1 sistemi koşullarının oluştuğu belirlenmiştir. \%4 oranında patates nişastası ilave edilen püre örnekleri şekillerini daha iyi koruduğu, ancak zayıf ekstrüde edilebilirlik ve yüksek viskozite nedeniyle yazıcı sisteminin çalışmasını zorlaştırdığı bildirilmiştir (Liu vd., 2018a; Pitayachaval vd., 2018).

\section{SONUÇ}

$\mathrm{Bu}$ derleme, gidalarda 3D yazıc1 sisteminin kullanım alanlarını ve nedenlerini örneklerle açıklamakta ve 3D model oluşturma ve dilimleme aşamalarından oluşan gıda yazıcı sisteminin ilk adımını özetleyerek ifade edilen aşamaların optimizasyonunu ortaya koymaktadır. Gidalarda 3D yazıc1 sistemi artık umut vaat eden yeni bir gıda işleme teknolojisi olarak kabul edilmekle birlikte, yine de belirli alanlarda farklı tüketici grupları için 3D baskı modellerinin tasarlanmasına yönelik daha fazla araştırmaya ve spesifik dilimleme yazılımı gelişimine ihtiyaç duyulmaktadır. 3D gida yazıcıs1, temel olarak çikolata, kurabiye gibi atıştırmalıklarda özelleştirilmiş uygulamalar olarak karşımıza çıkmakta olup özellikle son y1larda gida 
endüstrisinde yer alan araştırmacılar ve uygulayıcıların ilgi odağı haline gelmiştir. Ayrıca gidalarda 3D yazıcı teknolojisinin endüstriyel kullanımları için de büyük çaba sarf edilmiştir. 3D yazıc1 teknolojisinin potansiyellerini ortaya çıkarmak için konu ile ilgili spesifik olarak teknik yönden karşılaşılabilecek zorlukları dikkate almak gerekmektedir. Gidalarda 3D yazıcı sisteminde model oluşturma ve dilimleme yazılımı gibi teknik Özellikler araştırmaların ihtiyaçlarını karşılama noktasında yetersiz kalmaktadır. Bu nedenle, 3D yazıcı modellerini geliştirmeye yönelik araştırmalara ağırlık verilmesi gerekmektedir. Bunun yanı sıra et, meyve, sebze, pirinç gibi çeşitli geleneksel gida maddeleri doğal yapıları nedeniyle 3D yazıcı sisteminde kullanılamamaktadır. $\mathrm{Bu}$ bahsi geçen gida maddelerinin çeşitli hidrokolloidler ve enzimler ile yapisal olarak yazıc1 sisteminde kullanılabilir hale getirilmesi gerekmektedir. Bu ön hazırlık çalışmaları 3D yazıc1 teknolojisi zaman ve maliyet bazında kayıplara yol açarken kullanılan maddelere bağlı olarak lezzet ve besin değerlerinde kayıplara yol açabilmektedir. Ayrıca ürün bazında spesifik dilimleme yazılımlarının oluşturulması, disiplinli bir çalışma ve zaman gerektirmektedir. Tüm bu durumlar dikkate alındığında, gidalarda 3D yazıcı teknolojisinin kullanımında kolaylıkların yanında çeşitli zorlukların da bulunduğu ve teknoloji kullanımında ön çalışmaların dikkatle yapılması gerektiği görülmektedir.

Yazıc1 teknolojisinde kullanılan materyalleri, kullanım sürecindeki davranışlarını, gıda pazarına ve tüketici tarafindan geçerliliğini konu alan daha fazla araştırma yapılmalıdır. Daha da önemlisi, 3D yazıc1 teknolojisinde uygulama alanının atıştırmalıklardan daha çok besleyici gıdaların üretimine yönelmesi ve yazıcı sisteminin kullanımı ile gıdaların besleyici kalitesinin arttı̆ına dair bilginin tüketicilere daha net şekilde aktarılması gerekmektedir. $\mathrm{Bu}$ duruma ek olarak 3D yazıc1 sisteminin hangi sektörde yer alan kitleyi (çocuklar, hamileler, yaşlılar, sporcular, modern gastronomi tutkunlar1, askerler, astronotlar) hedeflediğini tanımlamak da önemlidir. Gerçekleştirilecek olan çalışmada hedefi belirlemek, 3D yazıcı teknolojisinde atılacak her adım için yolunuzu aydınlatacaktır; hangi gıda materyalleri, hangi teknoloji kullanılmalı, hangi modellerden yararlanılmalı sorularına cevap vererek ve tüm bu faktörleri birlikte değerlendirerek tüketici tercihine cevap veren en iyi teknolojiyi ortaya koymak için optimizasyon çalışmaları yapılmalıdır.

\section{ÇIKAR ÇATIŞMASI BEYANI}

Yazarların, başka kişiler ve/veya kurumlar ile çıkar çatışması bulunmamaktadır.

\section{YAZAR KATKILARI}

Aslihan Demirdöven ve Hilal Meral makaleyi birlikte planlamıs, yazım, inceleme ve düzenleme aşamalarında katkıda bulunarak, nihai halini okumuş ve onaylamıştır.

\section{KAYNAKLAR}

3dslash (2018). A 3D piece of cake. https://www.3dslash.net/slash.php (Erişim tarihi:10.06.2021).

Aday, S., Aday, M. S. Üç Boyutlu Yazıcıların Gıda Endüstrisinde Kullanımı. Türkiye 13. G1da Kongresi, 21-23 Ekim 2020, Çanakkale, Türkiye, $442 \mathrm{s.}$

Aldanmaz, E. A., Sever, R. (2017). Gidaların Dizaynında 3 Boyutlu Yazıc1 Teknolojisi Uygulamalar1. https://ab.org.tr/ab17/bildiri/ 242.pdf (Erişim tarihi: 28.05.2021)

Arsava, E.M., Aydoğdu, İ., Güngör, L., Togay Işıkay, C., Yaka, E. (2018). İnme hastalarında nütrisyonel yaklaşım ve tedavi, Türkiye için uzman görüşü. Türk Nöroloji Dergisi, 24: 226242, doi: 10.4274/tnd.92603.

Boissonneault, T. (2019). Upprinting food transforms food waste into edible 3D printed snacks. https://www.3dprintingmedia.network/ upprinting-food-food-waste-edible-3dprintedsnacks/ (Accessed: 10 June 2021).

Byflow. (2018). The first high-end restaurant in the netherlands with 3D-printed food on the menu. https://www.3dbyflow.com/post/thefirst-high-end-restaurant-in-the-netherlandswith-3d-printed-food-on-the-menu. (Accessed: 24 May 2021) 
Candoğan, K., Bulut, E. G. (2021). 3D Gida baskis1: Güncel Durum ve Gelecek Eğilimleri. Gıda, 46(1), 152-167. doi: 10.15237/gida.GD20130.

Chuanxing, F., Qi, W., Hui, L., Quancheng, Z., Wang, M. (2018). Effects of pea protein on the properties of potato starch-based 3D printing materials. Int. J. Food Eng, 14(3). doi: https://doi.org/10.1515/ijfe-2017-0297.

D'Angelo, G., Hansen, H. N., Hart, A. J. (2016). Molecular gastronomy meets 3D Printing: Layered construction via reverse spherification. 3D Printing and Additive Manufacturing, 3(3), 152159. doi: https://doi.org/10.1089/3dp. 2016.0024 .

Dankar, I., Haddarah, A., Omar, F. E., Sepulcre, F., Pujolà, M. (2018a). 3D printing technology: The new era for food customization and elaboration. Trends Food Sci. Technol., 75, 231-242. doi: https://doi.org/10.1016/j.tifs.2018.03.018.

Dankar, I., Haddarah, A., El Omar, F., Sepulcre, F., Pujolà, M. (2018b). Assessing the microstructural and rheological changes induced by food additives on potato puree. Food Chem. 240, 304-313. doi: https://doi.org/10.1016/j.foodchem.2017.07.12 1.

Değerli, C., El, S. N. (2017). Üç Boyutlu (3D) Yazıc1 Teknolojisi ile G1da Üretimine Genel Bakış. Turk. tarm gıda bilim teknol. derg., 5(6), 593599. doi: https://doi.org/10.24925/ turjaf.v5i6.593-599.1062.

Deloitte (2015). The 2015 American pantry study: The call to re-connect with consumers. https://www2.deloitte.com/content/dam/

Deloitte/us/Documents/consumer-

business/us-cb-2015-american-pantry-study.pdf. (Accessed: 05 May 2021).

de Roos, B. (2013). Personalised nutrition: Ready for practice? Proceedings of the Nutrition Society, 72(1), 48-52. https://www.cambridge.org/journals/. doi: https://doi.org/10.1017/S0029665112002844

Derossi, A., Caporizzi, R., Azzollini, D., Severini, C. (2018). Application of 3D printing for customized food. A case on the development of a fruit-based snack for children. J. Food Eng., 220, 65-75. doi: https://doi.org/10.1016/j.jfoodeng. 2017.05.015.

Dick, A., Bhandari, B., Prakash, S. (2019). 3D printing of meat. Meat Sci., 153, 35-44. doi: https://doi.org/10.1016/j.meatsci.2019.03.005

Dong, Z., Cui, H., Zhang, H., Wang, F., Zhan, X., Mayer, F., Levkin, P. A. (2021). 3D printing of inherently nanoporous polymers via polymerization-induced phase separation. Nature communications, 12(1), 1-12. doi: https://doi.org/10.1038/s41467-020-20498-1.

Godoi, F. C., Prakash, S., Bhandari, B. R. (2016). 3D Printing technologies applied for food design: Status and prospects. J. Food Eng., 179, 44-54. doi: https://doi.org/10.1016/j.jfoodeng.2016.01.025

Guo, C., Zhang, M., Bhandari, B. (2019). Model building and slicing in food 3D printing processes: a review. Compr Rev Food Sci F., 18(4), 1052-1069. doi: https://doi.org/10.1111/15414337.12443.

Hamilton, C. A., Alici, G., in het Panhuis, M. (2018). 3D printing vegemite and Marmite: Redefining "breadboards". J. Food Eng., 220, 8388. doi: https://doi.org/10.1016/j.jfoodeng. 2017.01.008.

Holland, S., Tuck, C., Foster, T. (2018). Selective recrystallization of cellulose composite powders and microstructure creation through 3D binder jetting. Carbohydr Polym., 200: 229-238. doi: https://doi.org/10.1016/j.carbpol.2018.07.064.

Horst, D. J. (2018). 3D printing of pharmaceutical drug delivery systems. Archives of Organic and Inorganic Chemical Sciences, 1(2), 1-5. doi: 10.2174/1381612825666181206123828.

iReviews (2014). 3D Systems Chef Jet Pro. http://3dfood-printers.www1.ireviews.com/3dsystems-chefjet-pro-review. (Accessed: 04 May 2021).

Izdebska, J., Zolek-Tryznowska, Z. (2016). 3D food printing - facts and future. Agro Food Industry Hi-Tech., 27(2), 33-39. 
Kim, H. W., Bae, H., Park, H. J. (2017). Classification of the printability of selected food for 3D printing: Development of an assessment method using hydrocolloids as reference material. J. Food Eng, 215, 23-32. doi: https://doi.org/10.1016/j.jfoodeng.2017.07.017.

Lanaro, M., Forrestal, D. P., Scheurer, S., Slinger, D. J., Liao, S., Powell, S. K., Woodruff, M. A. (2017). 3D printing complex chocolate objects: Platform design, optimization and evaluation. $J$. Food Eng, 215, 13-22. doi: https://doi.org/ 10.1016/j.jfoodeng.2017.06.029

Le Tohic, C., O'Sullivan, J. J., Drapala, K. P., Chartrin, V., Chan, T., Morrison, A. P., Kelly, A. L. (2018). Effect of 3D printing on the structure and textural properties of processed cheese. $J$. Food Eng., 220, 56-64. doi: https://doi.org/ 10.1016/j.jfoodeng.2017.02.003.

Lille, M., Nurmela, A., Nordlund, E., MetsaKortelainen, S., Sozer, N. (2018). Applicability of protein and fiber-rich food materials in extrusionbased 3D printing. J. Food Eng., 220, 20-27. doi: https://doi.org/10.1016/j.jfoodeng.2017.04.034

Lipton, J., Arnold, D., Nigl, F., Lopez, N., Cohen, D., Norén, N., (2010). Mutlimaterial food printing with complex internal structure suitable for conventional postprocessing. 21st annual international solid freeform fabrication symposium-an additive manufacturing conference (pp. 809-815).

Lipton, J. I., Cutler, M., Nigl, F., Cohen, D., Lipson, H. (2015). Additive manufacturing for the food industry-A review. Trends Food Sci. Technol., 43(1), 114-123. doi: https://doi.org/10.1016/ j.tifs.2015.02.004.

Liu, Z., Zhang, M., Bhandari, B., Wang, Y. (2017). 3D Printing: Printing precision and application in food sector. Trends Food Sci. Technol., 69, 83-94. doi: https://doi.org/10.1016/j.tifs.2017.08.018. Liu, Z., Zhang, M., Bhandari, B., Yang, C. (2018). Impact of rheological properties of mashed potatoes on 3D printing. J. Food Eng., 220, 76-82. doi: $\quad$ https://doi.org/10.1016/j.jfoodeng. 2017.04.017.

Mantihal, S., Prakash, S., Godoi, F. C., Bhandari, B. (2017). Optimization of chocolate 3D printing by correlating thermal and flow properties with 3D structure modeling. Innov Food Sci Emerg., 44, 21-29. doi: https://doi.org/10.1016/j.ifset. 2017.09.012.

Mantihal, S., Prakash, S., Bhandari, B. (2019). Texture-modified 3D printed dark chocolate: Sensory evaluation and consumer perception study. J. Texture Stud., 50(5), 386-399. doi: https://doi.org/10.1111/jtxs.12472.

Michaeli, J. G., DeGroff, M. C., Roxas, R. C. (2017). Error aggregation in the reengineering process from 3D scanning to printing. Scanning., 2017. https://doi.org/10.1155/2017/1218541.

Molitch-Hou, M. (2015). Bocusini plug \& play food 3D printer. 3D Printing Industry. https://3dprintingindustry.com/news/bocusiniplug-play-food-3d-printer-to-heat-up-kickstartertomorrow-48767/ . (Accessed: 01 July 2021)

Nasa, National Aeronautics and Space Administration (2013). 3D Printing: Food in space. https://www.nasa.gov/directorates/ spacetech/home/feature_3d_food.html.

(Accessed: 15 July 2021)

Ötleş, S. (2016). Gıda sektöründe üç boyutlu yazıcıların kullanım olanakları. Dünya Grda, 2016(11): 110-114.

Peppel, C. V. D. (2015). 3D food printing MSc Thesis. Wageningen University, Netherlands, Holland.

Pérez, B., Nykvist, H., Brøgger, A. F., Larsen, M. B., Falkeborg, M. F. (2019). Impact of macronutrients printability and 3D-printer parameters on 3D-food printing: A review. Food Chem., 287, 249-257.

Pitayachaval, P., Sanklong, N., Thongrak, A. (2018). A review of 3D food printing technology. In MATEC Web of Conferences (Vol. 213, p. 01012). EDP Sciences. doi: https://doi.org/10.1051/ matecconf/201821301012.

Prakash, S., Bhandari, B.R., Godoi, F.C., Zhang, M. (2019). Future outlook of 3D food printing. Fundamentals of $3 D$ Food Printing and Applications, Godoi, F.C. (ed.), Bhandari, B.R. (ed.), Prakash, S. (ed.), Zhang, M. (ed.), Academic Press, London, 
the UK, pp. 373-381. ISBN: 012814565X, 9780128145654 .

Rayna, T., Striukova, L. (2016). From rapid prototyping to home fabrication: How 3D printing is changing business model innovation. Technol Forecast Soc Change., 102, 214224. doi: https://doi.org/10.1016/j.techfore. 2015.07.023.

Severini, C., Derossi, A., Ricci, I., Caporizzi, R., Fiore, A. (2018). Printing a blend of fruit and vegetables. New advances on critical variables and shelf life of 3D edible objects. J. Food Eng., 220, 89-100. doi: https://doi.org/10.1016/j.jfoodeng. 2017.08.025

Shahbazi, M., Jäger, H. (2020). Current status in the utilization of biobased polymers for 3D printing process: a systematic review of the materials, processes, and challenges. ACS Appl. Bio Mater., 4(1), 325-369. doi: https://doi.org/ 10.1021/acsabm.0c01379.

Simon (2015). PepsiCo is creating new deepridged potato chips on 3D printers 3D Printer News \& 3D Printing News. https://3dfoodprintingconference.com/food/pe psico-is-creating-new-deep-ridged-potato-chipson-3d-printers/ (Accessed: 28 April 2021).

Sun, J., Peng, Z., Yan, L., Fuh, J. Y. H., Hong, G. S. H., Fuh, J. Y. (2015a). 3D food printing-an innovative way of mass customization in food fabrication. Int J. Bioprinting, 1(1), 27-38. doi: 10.18063/IJB.2015.01.006.

Sun, J., Zhou, W., Huang, D., Fuh, J. Y. H., Hong, G. S. (2015b). An Overview of 3D printing technologies for food fabrication Food Bioproc Tech., 8(8), 1605-1615). doi: 10.1007/s11947-0151528-6.

Tan, C., Yan Toh, W., Wong, G., Li, L. (2018). Extrusion-based 3D food printing - Materials and machines, Int J. Bioprinting, 4(2): 143. doi: 10.18063/IJB.v4i2.143.

Tess (2016). Columbia scientists are developing a $3 \mathrm{D}$ food printer that can cook your food https://www.3ders.org/articles/20160801columbia-engineers-are-developing-a-3d-food- printer-that-can-cook-your-food.html (Accessed: 02 June 2021).

Türker, İ., İşleroğlu, H. (2020). Gıda Mühendisliği ve Gastronomi Bilimi: Ortak Yaklaşımlar ve Ortak Gelişim. Journal of Tourism and Gastronomy Studies, 8(2), 1552-1577. doi: https://doi.org/ 10.21325/jotags.2020.621.

Vancauwenberghe, V., Katalagarianakis, L., Wang, Z., Meerts, M., Hertog, M., Verboven, P., Nicolai, B. (2017). Pectin based food-ink formulations for 3-D printing of customizable porous food simulants. Innov Food Sci Emerg., 42, 138-150. doi: https://doi.org/10.1016/j.ifset. 2017.06.011

Vialva, T. (2018). Novameat 3D prints vegetatian steak from plant-based proteins. https://3dprintingindustry.com/news/novameat -3d-prints-vegetarian-steak-from-plant-basedproteins-144722/. (Accessed: 15 May 2021).

Wang, L., Zhang, M., Bhandari, B., Yang, C. (2018). Investigation on fish surimi gel as promising food material for 3D printing. J. Food Eng, 220, 101-108. doi: https://doi.org/ 10.1016/j.jfoodeng.2017.02.029.

Warner, E.L., Norton, L.T., Mills, T.B. (2019). Comparing the viscoelastic properties of gelatin and different concentrations of kappacarrageenan mixtures for additive manufacturing applications. J. Food Eng., 246: 58-66. doi: https://doi.org/10.1016/j.jfoodeng.2018.10.033.

Watkin, H. (2016). World's first 3D printing restaurant opens in London. https://all3dp.com/ worlds-first-3d-printing-restaurantcoming-

london/. (Accessed: 02 April 2021).

Wiggers, K. (2017). From pixels to plate, food has become 3D printing's delicious new frontier.https://www.digitaltrends.com/cooltech/3d-food-printers-how-they-could-changewhat-you-eat/. (Accessed: 13 June 2021).

Yang, F., Zhang, M., Bhandari, B. (2017). Recent development in 3D food printing. Crit Rev Food., 57(14), 3145-3153. doi: https://doi.org/ 10.1080/10408398.2015.1094732.

Yang, F., Zhang, M., Bhandari, B., Liu, Y. (2018). Investigation on lemon juice gel as food material 
for $3 \mathrm{D}$ printing and optimization of printing parameters. LWT-Food Sci Technol., 87, 67-76. doi: https://doi.org/10.1016/j.lwt.2017.08.054

Yang, F., Guo, C., Zhang, M., Bhandari, B., Liu, Y. (2019). Improving 3D printing process of lemon juice gel based on fluid flow numerical simulation. LWT-Food Sci Technol., 102, 89-99. doi: https://doi.org/10.1016/j.lwt.2018.12.031.
Zoran, A., Coelho, M. (2011). Cornucopia: the concept of digital gastronomy. Leonardo, 44(5), 425-431. doi: https://doi.org/10.1162/ LEON_a_00243. 